TAHKIM, Jurnal Peradaban dan Hukum Islam. Vol.3 No.l (Maret, 2020) | ISSN : 2597-7962

\title{
ANALISIS HUKUM ISLAM TERHADAP PEMBENTUKAN DAERAH OTONOM BARU SEBAGAI UPAYA MENINGKATKAN KESEJAHTERAAN MASYARAKAT
}

\author{
Anwar Hidayat, Budiman \\ Fakultas Hukum Universitas Buana Perjuangan Karawang \\ Anwar.Hidayat@ubpkarwang.ac.id
}

\begin{abstract}
ABSTRAK
Islam memberikan perhatian pada seluruh tatanan kehidupan, termasuk dalam masalah kenegaraan. Tujuan hukum islam dalam melahirkan kemaslahatan bersama baik untuk negara maupun masyarakat merupakan amanat hukum Islam. Pemberlakuan sistem otonomi daerah merupakan amanat yang diberikan oleh UUD 1945 Amandemen Kedua tahun 2000 untuk dilaksanakan berdasarkan UU yang dibentuk khusus untuk mengatur pemerintahan daerah. UUD 1945 pasca-amandemen itu mencantumkan permasalahan pemerintahan daerah dalam Bab VI, yaitu Pasal 18, Pasal 18A, dan Pasal 18B. Namun, karena dianggap tidak sesuai lagi dengan perkembangan keadaan, ketatanegaraan, dan tuntutan penyelenggaraan otonomi daerah, maka aturan baru pun dibentuk untuk menggantikannya. Penelitian ini merupakan penelitian yuridis normative, untuk mengetahui pandangan Islam terkait otonomi daerah sebuah negara.
\end{abstract}

kata kunci: Daerah Otonomi, Pemekaran Wilayah, Kesejahteraan Sosial.

\section{ABSTRACT}

Islam pays attention to the whole order of life, including in matters of state. The purpose of Islamic law in giving birth to the benefit of both the state and society is the mandate of Islamic law. The enactment of the regional autonomy system is a mandate given by the 1945 Constitution of the Second Amendment in 2000 to be implemented based on a law that was formed specifically to regulate regional government. The postamendment 1945 Constitution lists the problems of regional government in Chapter VI, namely Article 18, Article 18A, and Article 18B. However, because it was considered no longer suitable to the development of the situation, state administration and demands for the implementation of regional autonomy, new rules were formed to replace it. This research is a normative juridical study, to find out Islam's view related to a country's regional autonomy.

Keywords: Autonomous Region, Regional Expansion, Social Welfare. 
TAHKIM, Jurnal Peradaban dan Hukum Islam. Vol.3 No.l (Maret, 2020) | ISSN : 2597-7962

\section{A. PENDAhULUAN}

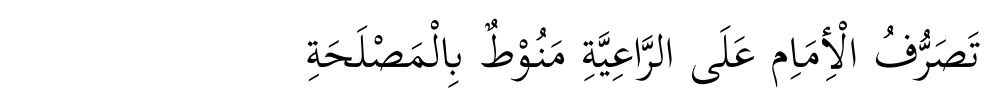

“ kebijakan pemimpin kepada rakyatnya harus sesuai dengan kemaslahatan atau kesejahteraan rakyatnya ${ }^{l,}$

Islam memberikan ruang ijtihad dalam wilayah siyasah atau politik atau bernegara asal demi kemaslahatan dan keadilan serta kesejahteraan secara umum. Otonomi daerah di Indonesia lahir di tengah gejolak sosial yang sangat massif pada tahun 1999. Gejolak sosial tersebut didahului oleh krisis ekonomi yang melanda Indonesia disekitar tahun 1997. Gejolak sosial yang melanda Negara Indonesia di sekitar tahun 1997kemudian melahirkan gejolak politik yang puncaknya ditandai dengan berakhirnya pemerintahan orde baru yang telah berkuasa selama kurang lebih 32 tahun di Indonesia.Setelah runtuhnya pemerintahan orde baru pada tahun 1998, mencuat sejumlah permasalahan terkait dengan sistem ketatanegaraan dan tuntutan daerah-daerah yang selama ini telah memberikan kontribusi yang besar dengan kekayaan alam yang dimilikinya. Wacana otonomi daerah kemudian bergulir sebagai konsepsi alternatif untuk menjawab permasalahan sosial dan ketatanegaraan Indonesia yang dianggap telah usang dan perlu diganti. Inilah yang menjadi latar belakang otonomi daerah di Indonesia.Di balik itu semua ternyata ada banyak faktor yang menjadi latar belakang otonomi daerah di Indonesia. Latar belakang otonomi daerah tersebut dapat dilihat secara internal dan eksternal.

Latar belakang otonomi daerah di Indonesia berdasarkan beberapa referensi dapat dilihat dari 2 aspek, yaitu pertama aspek internal yakni kondisi yang terdapat dalam negara Indonesia yang mendorong penerapan otonomi daerah di Indonesia. Kedua, aspek eksternal yakni faktor dari luar negara Indonesia yang mendorong dan mempercepat implementasi otonomi daerah di Indonesia. Latar belakang otonomi daerah secara internal, timbul sebagai tuntutan atas buruknya pelaksanaan mesin pemerintahan yang dilaksanakan secara sentralistik. Terdapat kesenjangan dan ketimpangan yang cukup besar antara pembangunan yang terjadi di daerah dengan pembangunan yang

\footnotetext{
${ }^{1}$ Ahmad Rofiq, Hukum Islam Di Indonesia, (Jakarta: PT.Grafindo Persada, 1998), hlm..120
} 
TAHKIM, Jurnal Peradaban dan Hukum Islam. Vol.3 No.l (Maret, 2020) | ISSN : 2597-7962

dilaksanakan di kota-kota besar, khususnya Ibukota Jakarta. Kesenjangan ini pada gilirannya meningkatkan arus urbanisasi yang di kemudian hari justru telah melahirkan sejumlah masalah termasuk tingginya angka kriminalitas dan sulitnya penataan kota di daerah Ibukota, oleh karena ini itu perlu dilihat aspek kemaslahatan yang menjadi amanat hukum Islam dan UUD 1945.

\section{B. METODE PENELITIAN}

Penelitian yang dilakuakn merupakan sebuah penelitian kualitatif dengan pendekatan daftar pustaka (review literatur), dengan metode pengumpulan datanya adalah melalui dokumentasi terkait dengan dokumen majalah, koran dll, atau melalui buku-buku kajian, serta perangkat peraturan undang-undang yang berkaitan dengan penelitian. Adapun analisis penelitian yang dilakukan dengan cara mengkategorikan, mengelompokan serta membandingakan data yang ada. Untuk mempertegas analisis penelitian maka peneliti melakukan diskusi dengan beberapa pengamat yang memiliki pemahaman yang tinggi terhadap masalah otonomi daerah dan pemekaran wilayah.

\section{PEMBAHASAN}

\section{Daerah Otonom dan Prinsip Dasar Daerah Otonom}

Daerah otonom adalah daerah di dalam suatu negara yang memiliki kekuasaan otonom, atau kebebasan dari pemerintah di luar daerah tersebut. Biasanya suatu daerah diberi sistem ini karena keadaan geografinya yang unik atau penduduknya merupakan minoritas negara tersebut, sehingga diperlukan hukum-hukum yang khusus, yang hanya cocok diterapkan untuk daerah tersebut. Menurut jenisnya, daerah otonom dapat berupa otonomi teritorial, otonomi kebudayaan, dan otonomi lokal. Di Indonesia, daerah otonom diartikan sebagai kesatuan masyarakat hukum yang mempunyai batas daerah tertentu, yang berwenang mengatur dan mengurus kepentingan masyarakat setempat menurut prakarsa sendiri berdasarkan aspirasi masyarakat dalam ikatan Negara Kesatuan Republik Indonesia.

Pemberlakuan sistem otonomi daerah merupakan amanat yang diberikan oleh Undang-Undang Dasar Negara Republik Indonesia Tahun 1945 (UUD 1945) Amandemen Kedua tahun 2000 untuk dilaksanakan berdasarkan undang-undang yang dibentuk khusus untuk mengatur pemerintahan daerah. UUD 1945 pasca-amandemen itu mencantumkan permasalahan pemerintahan daerah dalam Bab VI, yaitu Pasal 18, Pasal 
TAHKIM, Jurnal Peradaban dan Hukum Islam. Vol.3 No.l (Maret, 2020) | ISSN : 2597-7962

18A, dan Pasal 18B. Sistem otonomi daerah sendiri tertulis secara umum dalam Pasal 18 untuk diatur lebih lanjut oleh undang-undang. asal 18 ayat (2) menyebutkan, "Pemerintahan daerah provinsi, daerah kabupaten, dan kota mengatur dan mengurus sendiri urusan pemerintahan menurut asas otonomi dan tugas pembantuan. "Selanjutnya, pada ayat (5) tertulis, "Pemerintahan daerahmenjalankan otonomi seluas-luasnya kecuali urusan pemerintahan yang oleh undang-undang ditentukan sebagai urusan pemerintah pusat." Dan ayat (6) pasal yang sama menyatakan, "Pemerintahan daerah berhak menetapkan peraturan daerah dan peraturan-peraturan lain untuk melaksanakan otonomi dan tugas pembantuan ${ }^{2}$."Secara khusus, pemerintahan daerah diatur dalam UndangUndang Nomor 22 Tahun 1999 tentang Pemerintahan Daerah. Namun, karena dianggap tidak sesuai lagi dengan perkembangan keadaan, ketatanegaraan, dan tuntutan penyelenggaraan otonomi daerah, maka aturan baru pun dibentuk untuk menggantikannya. Pada 15 Oktober 2004, Presiden Megawati Soekarnoputri mengesahkan Undang-Undang Nomor 32 Tahun 2004 tentang Pemerintahan Daerah. Undang-Undang Nomor 32 Tahun 2004 tentang Pemerintahan Daerah (UU Nomor 32 Tahun 2004) memberikan definisi otonomi daerah sebagai berikut. "Otonomi daerah adalah hak, wewenang, dan kewajiban daerah otonom untuk mengatur dan mengurus sendiri urusan pemerintahan dan kepentingan masyarakat setempat sesuai dengan peraturan perundang-undangan”. UU Nomor 32 Tahun 2004 juga mendefinisikan daerah otonom sebagai berikut. "Daerah otonom, selanjutnya disebut daerah, adalah kesatuan masyarakat hukum yang mempunyai batas-batas wilayah yang berwenang mengatur dan mengurus urusan pemerintahan dan kepentingan masyarakat setempat menurut prakarsa sendiri berdasarkan aspirasi masyarakat dalam sistem Negara Kesatuan Republik Indonesia4."Dalam sistem otonomi daerah, dikenal istilah desentralisasi, dekonsentrasi, dan tugas pembantuan. Desentralisasi adalah penyerahan wewenang pemerintahan oleh pemerintah pusat kepada daerah otonomi untuk mengatur dan mengurus urusan pemerintahan dalam sistem Negara Kesatuan Republik Indonesia, ${ }^{3}$ Sedangkan dekonsentrasi adalah pelimpahan wewenang pemerintahan oleh pemerintah pusat kepada gubernur sebagai wakil pemerintah pusat di daerah dan/atay kepada instansi vertikal di wilayah tertentu. Sementara itu, tugas pembantuan merupakan penugasan dari

\footnotetext{
${ }^{2}$ Undang-Undang Dasar Negara Republik Indonesia Tahun 1945, Pasal. 18.

${ }^{3}$ Undang-Undang Tentang Pemerintahan Daerah, No. 32 Tahun 2004, Ln No.125 Tahun 2004, Tln No. 4437.
} 
TAHKIM, Jurnal Peradaban dan Hukum Islam. Vol.3 No.l (Maret, 2020) | ISSN : 2597-7962

pemerintah pusat kepada daerah dan/atau desa dari pemerintah provinsi kepada kabupaten/kota dan/atau desa serta dari pemerintah kabupaten/kota kepada desa untuk melaksanakan tugas tertentu.

Sebagai konsekuensi pemberlakuan sistem otonomi daerah di Indonesia, maka dibentuk pula perangkat peraturan perundang-undangan yang mengatur mengenai perimbangan keuangan antara pemerintah pusat dan daerah, yaitu Undang-Undang Nomor 25 Tahun 1999 tentang Perimbangan Keuangan antara Pemerintah Pusat dan Daerah (UU Nomor 25 Tahun 1999) yang kemudian diganti dengan Undang-Undang Nomor 33 Tahun 2004 tentang Perimbangan Keuangan antara Pemerintah Pusat dan Daerah (UU Nomor 33 Tahun 2004). Selain itu, amanat UUD 1945 yang menyebutkan bahwa, "Gubernur, Bupati, dan Walikota masing-masing sebagai kepala pemerintah daerah provinsi, kabupaten, dan kota dipilih secara demokratis" direalisasikan melalui Peraturan Pemerintah Nomor 6 Tahun 2005 tentang Pemilihan, Pengesahan, Pengangkatan, dan Pemberhentian Kepala Daerah dan Wakil Kepala Daerah.

\section{Dasar Hukum Otonomi Daerah}

UUD 1945 tidak mengatur perihal pembentukan daerah atau pemekaran suatu wilayah secara khusus, namun disebutkan dalam Pasal 18B ayat (1) bahwa, Negara mengakui dan menghormati satuan-satuan pemerintahan daerah yang bersifat khusus atau bersifatistimewa yang diatur dengan undang-undang. Selanjutnya, pada ayat (2) pasal yang sama tercantum kalimat sebagai berikut. "Negara mengakui dan menghormati kesatuan-kesatuan masyarakat hukum adat beserta hak-hak tradisionalnya sepanjang masih hidup dan sesuai dengan perkembangan masyarakat dan prinsip Negara Kesatuan Republik Indonesia, yang diatur dalam undang-undang5.

Secara lebih khusus, UU Nomor 32 Tahun 2004 mengatur ketentuan mengenai pembentukan daerah dalam Bab II tentang Pembentukan Daerah dan Kawasan Khusus. Dapat dianalogikan, masalah pemekaran wilayah juga termasuk dalam ruang lingkup pembentukan daerah. UU Nomor 32 Tahun 2004 menentukan bahwa pembentukan suatu daerah harus ditetapkan dengan undang-undang tersendiri. Ketentuan ini tercantum dalam Pasal 4 ayat (1). Kemudian, ayat (2) pasal yang sama menyebutkan sebagai berikut. "Undang-undang pembentukan daerah sebagaimana dimaksud pada ayat (1) antara lain mencakup nama, cakupan wailayah, batas, ibukota, kewenangan menyelenggarakan 
TAHKIM, Jurnal Peradaban dan Hukum Islam. Vol.3 No.l (Maret, 2020) | ISSN : 2597-7962

urusan pemerintahan, penunjukan penjabat kepala daerah, pengisian keanggotaan DPRD, pengalihan kepegawaian, pendanaan, peralatan, dokumen, serta perangkat daerah.

Legalisasi pemekaran wilayah dicantumkan dalam pasal yang sama pada ayat berikutnya ayat (3) yang menyatakan bahwa, "Pembentukan daerah dapat berupa penggabungan beberapa daerah atau bagian daerah yang bersandingan atau pemekaran dari satu daerah menjadi dua daerah atau lebih." Dan ayat (4) menyebutkan, "Pemekaran dari satu daerah menjadi 2 (dua) daerah atau lebih sebagaimana dimaksud pada ayat (3) dapat dilakukan setelah mencapai batas minimal usia penyelenggaraan pemerintahan. Namun demikian, pembentukan daerah hanya dapat dilakukan apabila telah memenuhi syarat administratif, teknis, dan fisik kewilayahan. Bagi provinsi, syarat administratif yang wajib dipenuhi meliputi adanya persetujuan DPRD kabupaten/kota dan bupati/walikota yang akan menjadi cakupan wilayah provinsi bersangkutan, persetujuan DPRD provinsi induk dan gubernur, serta rekomendasi dari Menteri Dalam Negeri. Sedangkan untuk kabupaten/kota, syarat administratif yang juga harus dipenuhi meliputi adanya persetujuan DPRD kabupaten/kota dan bupati/walikota bersangkutan, persetujuan DPRD provinsi dan gubernur, serta rekomendasi dari Menteri Dalam Negeri.

Selanjutnya, syarat teknis dari pembentukan daerah baru harus meliputi faktor yang menjadi dasar pembentukan daerah yang mencakup faktor-faktor di bawah ini.

a) Kemampuan ekonomi.

b) Potensi daerah.

c) Sosial budaya.

d) Sosial politik.

e) Kependudukan.

f) Luas daerah.

g) Pertahanan.

h) Keamanan.

i) Faktor lain yang memungkinkan terselenggaranya otonomi daerah.

Terakhir, syarat fisik yang dimaksud harus meliputi paling sedikit lima kabupaten/kota untuk pembentukan provinsi dan paling sedikit lima kecamatan untuk 
TAHKIM, Jurnal Peradaban dan Hukum Islam. Vol.3 No.l (Maret, 2020) | ISSN : 2597-7962

pembentukan kabupaten, dan empat kecamatan untuk pembentukan kota, lokasi calon ibukota, sarana, dan prasarana pemerintahan.

\section{Pelanksanaan Daerah Otonomi di Indonesia}

Otonomi daerah yang dicanangkan sejak Januari 2009 telah membawa perubahan politik di tingkat lokal (daerah). Salah satunya adalah menguatnya peran Dewan Perwakilan Rakyat Daerah (DPRD). Jika di masa sebelumnya DPRD hanya sebagai stempel karet dan kedudukannya di bawah legislatif, setelah otonomi daerah, peran legislatif menjadi lebih besar, bahkan dapat memberhentikan kepala daerah.

Pemberlakuan otonomi daerah beserta akibatnya memang amat perlu dicermati. Tidak saja memindahkan. Potensi korupsi dari Jakarta ke daerah, otonomi daerah juga memunculkan raja-raja kecil yang mempersubur korupsi, kolusi, dan nepotisme. Di samping itu, dengan adanya otonomi daerah, arogansi DPRD semakin tidak terkendali karena mereka merupakan representasi elite lokal yang berpengaruh. Karena perannya itu, di tengah suasana demokrasi yang belum Indonesia terbangun di tingkat lokal, DPRD akan menjadi kekuatan politik baru yang sangat rentan terhadap korupsi. Sebagaimana diamanatkan UU Nomor 23 Tahun 2014, publik seharusnya dilibatkan dalam pembuatan kebijakan. Namun, di beberapa daerah yang sudah mengadopsi sistem otonomi daerah, kenyataan yang terjadi masih jauh dari harapan. Pengambilan keputusan belum melibatkan publik dan masih berada di lingkaran elite lokal provinsi dan kabupaten/kota6. Belum terlibatnya publik dalam pembuatan kebijakan itu tercermin dari pembuatan peraturan daerah (perda). ${ }^{4}$

Walaupun pelaksanaan otonomi daerah lebih memikirkan peningkatan pendapatan daerah, seperti yang ditunjukkan dari ringkasan penelitian tentang desentralisasi di 13 kabupaten/kota di Indonesia, implementasi otonomi daerah selain telah mendekatkan pemerintah setempat dengan masyarakat, juga mendorong bangkitnya partisipasi warga. Otonomi daerah, di lain pihak, memperkenalkan kecenderungan baru, yaitu banyaknya lembaga sosial masyarakat baru yang bertujuan untuk mengatasi konflik, perbedaan etnis, dan masalah sosial-ekonomi dengan bantuan minimal dari pemerintah lokal. Pemerintah lokal juga mencoba mengadopsikan peran aktif mengasimilasi kepentingan golongan

${ }^{4}$ Deddy Supriadi Bratakussumah, Riyadi. Perencanaan Pembangunan Daerah (Strategi Menggali Potensi Dalam Mewujudkan Otonomi Daerah). (Jakarta: Pt. Gramedia Pustaka Utama, 2003), hlm.339. 
TAHKIM, Jurnal Peradaban dan Hukum Islam. Vol.3 No.l (Maret, 2020) | ISSN : 2597-7962

minoritas. Untuk mengatasi masalah asimilasi, pada awal 1970-an, Presiden Soeharto membentuk Badan Kesatuan Bangsa dan Pembaruan Masyarakat (BKBPM), dan setelah reformasi, mengubah namanya menjadi Badan Kesatuan Bangsa (BKB). Badan ini memberikan dana kepada lembaga swadaya masyarakat (LSM) yang bertujuan untuk menjalankan program asimilasi dan membangkitkan sensitif suku, agama, ras, dan antargolongan (SARA) dan saling pengertian antarkelompok minoritas. Program BKB juga menggunakan LSM dan aparat pemerintah dalam membangun program asimilasi kebudayaan dan kelompok etnis plural. ${ }^{5}$

4. Pembentukan Daerah Otonomi Baru Sebagai Upaya Kesejahteraan Masyarakat menurut Hukum Islam

Pembentukan Daerah Otonomi Baru (DOB) bisa menjadi solusi peningkatan kesejahteraan dan pemerataan pembangunan di suatu daerah. Pemberian otonomi kepada daerah memberikan ruang yang luas bagi daerah untuk menggali dan mengembangkan potensi yang dimiliki sebagai upaya meningkatkan pelayanan publik. Dinamika yang berkembang dimasyarakat dari tahun ke tahun selalu mengharapkan adanya peningkatan pelayanan publik, potensi ekonomi, sosial budaya, pariwisata mau pun sumber daya alam. Pada tataran implementasi dalam rangka meningkatkan kesejahteraan masyarakat pada suatu daerah dibutuhkan komitmen pemerintah daerah dalam upaya jalinan kerja sama daerah. Salah satu tujuan pembentukan daerah otonomi baru adalah untuk meningkatkan kesejahteraan masyarakat daerah dengan mengedepankan kepentingan masyarakat untuk memperoleh kesejahteraan yang layak setara dengan daerah-daerah dengan pendapatan yang tinggi. Dengan dibentuknya daerah otonomi baru diharapkan masyarakat bisa mengeksploitasi potensi-potensi yang ada di daerahnya masing-masing. Sebagaimana kaidah fiqih berikut:

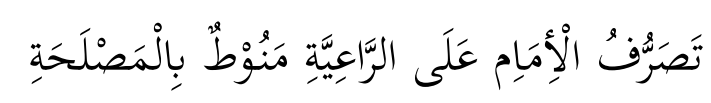

“ kebijakan pemimpin kepada rakyatnya harus sesuai dengan kemaslahatan atau kesejahteraan rakyatnya ${ }^{6,}$

5 Kendra Clegg, "Dari Nasionalisasi Ke Lokalisasi: Otonomi Daerah Di Lombok” Dalam Desentralisasi Globalisasi Dan Demokrasi Lokal, Editor Jamil Gunawan, (Jakarta: Lp3es, 2005), Hlm. 193.

${ }^{6}$ Ahmad Rofiq, Hukum Islam ....Hlm.120 . 
TAHKIM, Jurnal Peradaban dan Hukum Islam. Vol.3 No.l (Maret, 2020) | ISSN : 2597-7962

Hukum Islam memberi peluang kepada masyarakat untuk berubah, maju dan dinamis. Namun kemajuan dan kedinamisannya harus tetap dalam batas-batas prinsip Al-Quran. Prinsip umum itu adalah Tauhidullah (keyakinan kepada Allah SWT), persaudaraan, persatuan dan keadilan ${ }^{7}$. Dari kaidah fiqih di atas tersebut mengisyaratkan bahwa pemerintah sebagai pemangku kebijakan seharusnya memperhatikan aspek kemaslahatan semua pihak, khususnya daerah-daerah yang menjadi wilayah kekuasaannya. Agar kesejahteraan masyarakat dapat terjamin disemua daerah, sehingga ketimpangan ekonomi dapat dihindari. Serta harta dalam konteks kemajuan ekonomin dapat diakses oleh semua elemen seperti firman Allah ta'ala:

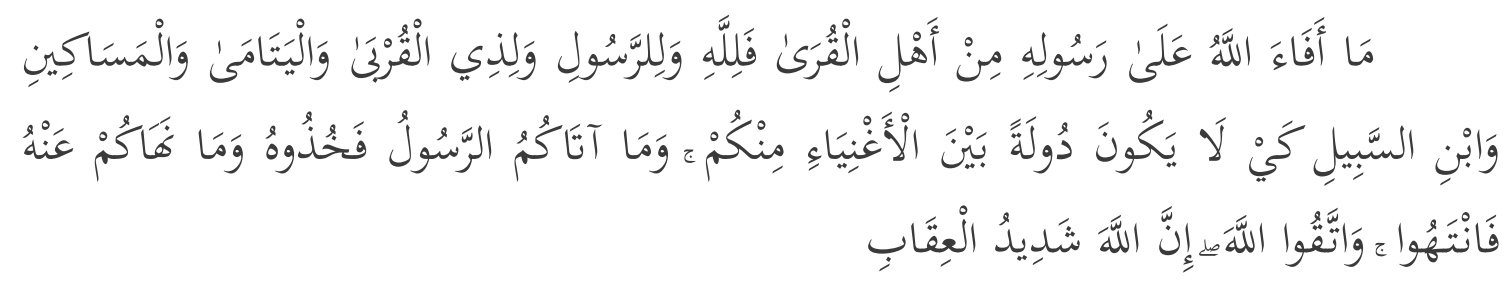

"Apa saja harta rampasan (fai-i) yang diberikan Allah kepada Rasul-Nya (dari harta benda) yang berasal dari penduduk kota-kota maka adalah untuk Allah, untuk Rasul, kaum kerabat, anak-anak yatim, orang-orang miskin dan orang-orang yang dalam perjalanan, supaya harta itu jangan beredar di antara orang-orang kaya saja di antara kamu. Apa yang diberikan Rasul kepadamu, maka terimalah. Dan apa yang dilarangnya bagimu, maka tinggalkanlah. Dan bertakwalah kepada Allah. Sesungguhnya Allah amat keras hukumannya".( Al-Hasyr [59] :7)

Dalam pembentukan daerah otonomi adalah hanya terfokus bagaimana suatu daerah otonomi mampu mengelola pemerintahan, keuangan, dan kepentingan publik lainnya dengan baik. Bahkan lebih jauh, dengan dikeluarkannya UU No 33 Tahun 2004 tentang perimbangan keuangan antara pemerintah pusat dan daerah, yang penekanannya lebih kepada bagaimana daerah otonomi mengelola APBD-nya dengan baik. Hal itulah yang membuat setiap daerah merasa terbebani dan sibuk untuk mengimplementasikan UU tersebut. Otonomi daerah yang sebenarnya bertujuan untuk memaksimalkan kewenangan daerah dalam membangun kemandiriannya, bukan hanya dalam mengelola APBD dan roda pemerintahannya, tetapi lebih dari itu adalah bagaimana setiap daerah mampu memaksimalkan potensi-potensi sumber daya yang dimilikinya. Normalnya

\footnotetext{
${ }^{7}$ Siska Lis Sulistiani, Perbandingan Sumber Hukum Islam. Jurnal Tahkim, Jurnal Peradaban dan hukum Islam Fakultas Syariah Unisba Vol.1 NO.1 Maret 2018, hlm.115.
} 
TAHKIM, Jurnal Peradaban dan Hukum Islam. Vol.3 No.l (Maret, 2020) | ISSN : 2597-7962

dengan otonomi, ketergantungan daerah kepada 'perhatian' pemerintah pusat semakin lama semakin berkurang, bukan hanya dalam urusan birokrasi, tetapi juga dalam sumber daya ekonomi dan pengelolaan daerah itu sendiri. ${ }^{8}$

\section{SIMPULAN DAN SARAN}

\section{Simpulan}

Daerah otonom adalah daerah di dalam suatu negara yang memiliki kekuasaan otonom, atau kebebasan dari pemerintah di luar daerah tersebut. Biasanya suatu daerah diberi sistem ini karena keadaan geografinya yang unik atau penduduknya merupakan minoritas negara tersebut, sehingga diperlukan hukum-hukum yang khusus, yang hanya cocok diterapkan untuk daerah tersebut. Menurut jenisnya, daerah otonom dapat berupa otonomi teritorial, otonomi kebudayaan, dan otonomi lokal.

UUD 1945 tidak mengatur perihal pembentukan daerah atau pemekaran suatu wilayah secara khusus, namun disebutkan dalam Pasal 18B ayat (1) bahwa, Negara mengakui dan menghormati satuan-satuan pemerintahan daerah yang bersifat khusus atau bersifatistimewa yang diatur dengan undang-undang.

Pembentukan Daerah Otonomi Baru (DOB) bisa menjadi solusi peningkatan kesejahteraan dan pemerataan pembangunan di suatu daerah. Pada tataran implementasi dalam rangka meningkatkan kesejahteraan masyarakat pada suatu daerah dibutuhkan komitmen pemerintah daerah dalam upaya jalinan kerja sama daerah.

\section{Saran}

Implementasi pembentukan daerah Otonomi Baru di Indonesia perlu di tingkatkan kembali seiring dengan laju pertumbuhan Ekonomi Di Indonesia yang cukup signifikan. Agar masyarakat di daerah bisa mengeksploitasi daripada potensi-potensi di daerah. yang bertujuan untuk mensejahterakan masyarakat daerah dan juga demi terciptanya hubungan yang baik antara pemerintahan pusat dan daerah.

Potensi penyalahgunaan wewenang pemerintahan Daerah otonomi Baru hedaknya bisa diatasi dengan menjalin kerjasama pemerintahan pusat dan pemerintah daerah

${ }^{8}$ Muhammad Reza . Analisis Pemekaran Daerah Dihubungkan Dengan Tujuan Otonomi Daerah (Studi Kasus Di Kabupaten Pontianak). Gloria Yuris Jurnal Hukum Prodi Ilmu Hukum Untan Vol. 2 No.3. 
TAHKIM, Jurnal Peradaban dan Hukum Islam. Vol.3 No.l (Maret, 2020) | ISSN : 2597-7962

dengan lembaga-lembaga terkait, agar tujuan dari pembentukan daerah otonomi baru tersebut yaitu kesejahteraan masyarakat bisa tercapai dengan baik.

\section{DAFTAR PUSTAKA}

Agustono, B. (2005). Otonomi Daerah dan Dinamika Politik Lokal: Studi Kasus di Kabupaten Deli Serdang, Sumatera Utara dalam Desentralisasi Globalisasi dan Demokrasi Lokal, editor Jamil Gunawan, Jakarta: LP3ES.

Bratakussumah, D. S., (2003). Riyadi. Perencanaan Pembangunan Daerah (Strategi Menggali Potensi Dalam Mewujudkan Otonomi Daerah). Jakarta: PT. Gramedia Pustaka Utama.

Reza, M. (2014). Analisis Pemekaran Daerah Dihubungkan Dengan Tujuan Otonomi Daerah (Studi Kasus Di Kabupaten Pontianak). Gloria Yuris Jurnal Hukum Prodi Ilmu Hukum UNTAN Vol. 2 No.3 .

Rofiq, Ahmad. (1998). Hukum Islam Di Indonesia, Jakarta: PT.Grafindo Persada.

Sulistiani, S.L. (2018). Perbandingan Sumber Hukum Islam. Jurnal Tahkim, Jurnal Peradaban dan hukum Islam Fakultas Syariah Unisba Vol.1 NO.1 Maret 2018.

Undang-Undang Dasar Negara Republik Indonesia Tahun 1945

Undang-Undang Tentang Pemerintahan Daerah, No. 32 Tahun 2004 